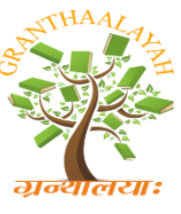

\author{
INTERNATIONAL JOURNAL OF RESEARCH - \\ GRANTHAALAYAH \\ A knowledge Repository
}

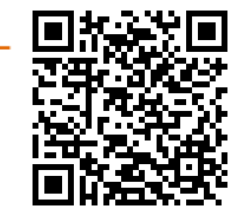

Social

\title{
CAUSES AND EFFECTS OF STUDENT TEACHER ABSENTEEISM IN TEACHER EDUCATION INSTITUTION
}

\author{
Dr. B. S. Gupta *1 \\ ${ }^{* 1}$ Department of Teacher Education, NGBV, Allahabad, UP, India
}

\begin{abstract}
A school was a place to get knowledge. A student absentee is a major concern for lecturers at institutions of teacher education learning. Absences create a dead, tiresome, unpleasant classroom environment that makes students who come to class uncomfortable and the lecturer irritable. The objective of the study was to study the causes of student teacher absentees in teacher education institution. The investigator selected the sample through random sampling, 994 student teachers were selected from teacher education institution from Allahabad. To collect the data researcher has used Absenteeism Inventory constructed by researcher. The salient finding of the study was the Male student teachers are more absent in their Teacher education Institution than Female student teachers and student teachers in Private Teacher education Institution are more absent in their Teacher education Institution than student teachers in Government Teacher education Institution.
\end{abstract}

Keywords: Teacher Education; Student Absentee; Learning.

Cite This Article: Dr. B. S. Gupta. (2017). "CAUSES AND EFFECTS OF STUDENT TEACHER ABSENTEEISM IN TEACHER EDUCATION INSTITUTION.” International Journal of Research - Granthaalayah, 5(7), 480-484.

\section{Introduction}

A school was a place to get knowledge. A student absentee is a major concern for lecturers at institutions of teacher education learning. Absences create a dead, tiresome, unpleasant classroom environment that makes students who come to class uncomfortable and the lecturer irritable. An absentee disturb the dynamic teaching-learning environment and adversely affects the overall well-being of classes (Segal 2008). In quality terms, absentees are a waste of educational resources, time and human potential. Student absentees also cause rework and wasted time for lecturers. Lecturers who spend class time re-teaching lessons take instructional time away from students who attend class regularly, and the extra time spent going over absentee homework and class assignments takes time away from lecturer planning periods and time needed to provide individual assistance (Weller 1996). When students are absent from class, they miss valuable information resulting from peer-lecturer interaction and the benefits of the specific 
examples lecturers use to clarify difficult concepts. This valuable part of the learning experience cannot be replicated when lecturers re-teach the material to absentee students

It is important to note that a primary issue of chronic absentees is not that there is no excuse provided, but rather, the excuse is not a valid one. According to Williams (2000), students who have absenteeism problems generally suffer academically and socially. Studies indicate that students who are absent have lower achievement and may be penalized on test scores (. Sustained absences may affect retention as it may degenerate into truancy (Lotz and Lee 1999; Barker and Jansen 2000).

Studies indicate that absentees is caused by a number of factors such as: lack of interesting and challenging curriculum; a desire for hedonistic activities with peers; negative self-image and self-esteem; lack of subject interest; lack of personal interest in studies; the mental capacity of a student does not match with the course opted; the poor teaching skills of a lecturer also keep away students from school; lack of confidence in a lecturer; inadequate relations between a student and their lecturer and distance to university. It is, therefore, against this background that this empirical study sought to investigate the causes and effects of student absentees in teacher education Institution.

\section{Objectives}

1) To study the causes of student teacher absentees in teacher education institution.

2) To Study the absenteeism of Male and Female student teachers in teacher education Institution.

3) To Study the absenteeism of student teachers in Government and Private teacher education Institution.

4) To study the effects of student teacher absentees in teacher education Institution.

\section{Null Hypothesis}

1) There is no difference in absenteeism between Male and Female student teachers in teacher education Institution.

2) There is no difference in absenteeism between student teachers of Government and Private Teacher education Institution.

\section{Methodology}

The research design that was used in this study was the descriptive survey method. The study employed mixed methodology. A quantitative and qualitative approach was adopted to gather more precise and quantifiable information on the causes and effects of absenteeism.

\section{Population and Sample}

The population for this study was all the student teacher of teacher education institute of Allahabad, UP. As sample 994 student teacher were Each University contributed 994 participants (Government (Male-164 \& Female-296) and Private (Male-151 \& Female-383)). The research used a convenience sample and the participation to the study was voluntary. 


\section{Tools Used}

In this study self-administered questionnaires with open- ended and closed questions were used for data collection. Interviews were also held with some of the students. Through the use of interviews, the interviewer was able to elaborate on issues and questions as well as clarifying the meaning of statements, answers or questions that may not have been clear to the interviewee. Semi-structured interviews were conducted because the researchers wanted the respondents to give their detailed views, opinions and perceptions with regard to causes of student absenteeism.

\section{Used Statistics}

For quantitative data percentages descriptive statistics were used. In analyzing qualitative data, categories were identified and put into themes for presentation and discussion.

\section{Results}

From the findings of this research, it became evident that the problem of absentees was quite prevalent in the three universities that participated in the study. This study sought to isolate major factors that give rise to this problem.

Objectives 1: To study the causes of student teacher absenteeism in teacher education Institution.

The findings of the study thus revolved around the following categories.

- Incidence of Absenteeism

- Low attendance Due to Part-time Jobs or Other Work-related Commitments

- Low attendance so as to Catch-up on or Completing Work to do with Studies

- Low attendance Due to Lecturers Whom I Dislike

- Low attendance Due to Uninteresting Courses/Subjects

- Missing Classes to be with Friends and Peers

- Non- Suitable and required facilities

Objectives 2: To Study the absenteeism of Male and Female student teachers in teacher education Institution.

Table 1: Mean SD and T-ratio of absentees of Male and Female student teachers in Teacher education Institution.

\begin{tabular}{|l|l|l|l|l|}
\hline \multicolumn{1}{|c|}{ Variable } & \multicolumn{1}{c|}{ No. } & \multicolumn{1}{c|}{ Mean } & \multicolumn{1}{c|}{ SD } & t-value \\
\cline { 1 - 4 } Male & 164 & 45.42 & 11.996 & \\
\cline { 1 - 4 } Female & 151 & 38.92 & 11.24 & $2.301^{*}$ \\
\hline
\end{tabular}

*.05 level of significance

From the table- 01 it is clear that the calculated value of t-ratio 2.301 is greater than the table value of t-ratio at .05 level of significance. Therefore the null hypothesis is rejected at .05 level of significance that 'There is no difference in absentees of Male and Female student teachers in Teacher education institutes' and the research hypothesis is accepted that 'There is difference in absentees of Male and Female student teachers in Teacher education Institution. Hence it is 
stated that there is significant difference in absentees of Male and Female student teachers in Teacher education Institution.

It is observed from Table 01 that the Mean of absentees of Male student teachers in Teacher education Institution is 45.42 and the Mean of absentees of Female student teachers in Teacher education Institution is 38.92. It indicates that there exists significant difference in absentees of Male and Female student teachers in Teacher education Institution. So it is stated that Male student teachers are more absent in their Teacher education Institution than Female student teachers. There are so many reasons-

1) Male student teachers think less than Female student teacher.

2) Male student teachers are more jobs oriented than Female student teacher.

3) Male student teachers are extrovert and social person than Female student teacher.

4) Both Student teachers are not satisfied with the availability of resources in their Teacher education Institution.

Objectives 3: To Study the absenteeism of student teachers in Government and Private teacher education Institution.

Table 2: Mean SD and T-ratio of absentees of student teachers in Government and Private Teacher education Institution.

\begin{tabular}{|l|l|l|l|l|}
\hline \multicolumn{1}{|c|}{ Variable } & \multicolumn{1}{c|}{ No. } & \multicolumn{1}{c|}{ Mean } & \multicolumn{1}{c|}{ SD } & t-value \\
\hline Government & 164 & 24.39 & 08.84 & \multirow{2}{*}{$24.57^{*}$} \\
\hline Private & 151 & 54.42 & 12.65 & 2 \\
\hline
\end{tabular}

*.05 level of significance

It is observed from Table 02 that the Mean of absentees of student teachers in Government Teacher education Institution is 45.42 and the Mean of absentees of student teachers in Private Teacher education Institution is 38.92. It indicates that there exists significant difference in absentees of student teachers in Government and Private Teacher education Institution. So it is stated that student teachers in Private Teacher education Institution are more absent in their Teacher education Institution than student teachers in Government Teacher education Institution. There are so many reasons-

1) Private Teacher educations Institution are money oriented than Government Teacher education Institution.

2) Teachers of Private Teacher education Institution are getting less salary so they are less interested in teaching and they engaged anywhere else than Government Teacher education Institution.

3) Students of Private Teacher education Institution are engaged for job and they want to get Degree easily than Government Teacher education Institution.

Objectives 4: To study the effects of student teacher absentees in teacher education Institution.

1) The aims and objective of education kept away

2) Student will be no serious about their education and academic achievement

3) Student are getting so many marks in their examination but mark are elusion not original

4) Increase literate unemployment day by day if it is not controlled. 


\section{Conclusion}

This study has shown that the problem of absenteeism is quite prevalent in teacher education. The problem is precipitated by interplay of a multiplicity of factors which are both internal and external to the student and or the teacher education Institution. Key among the factors that give rise to absentees are poor teaching strategies by lecturers, unfavorable learning environments, poor socio-economic background, peer influence as well as un conducive interpersonal relations between students teacher and trainers. The problem of student absentees is gaining much attention from educators, researchers and policy makers as it is not just an educational problem but also a social and political issue with huge social costs. The following reconditions are-

- The University Teaching and Learning Centers should identify training needs and organize symposiums, workshops, conferences and staff development programmes for lecturers so as to enhance their skills and performance levels.

- Obviously one way of operationaliazing this ideal is through the use of innovative teaching methods, the use of better equipped classrooms and a change in attitude.

- The implementation of effective and functional student orientation and student support programmes could be part of the intervention strategies that universities might need to consider among others.

- Students need regular guidance and counseling services as well as career support so that they may be able to cope with university life.

\section{References}

[1] Agresti, A., Franklin, C. (2007) Statistics: The Art and Science of Learning from Data (2nd Edition) at http://www.usablestats.com/calcs/2samplet\&summary=1

[2] Baldacchino G, Farrugia CF 2002. Educational Planning and Management in Small States. Concepts and Experiences. London: Marlborough House.

[3] Barker D, Jansen J 2000. Using groups to reduce elementary school absenteeism. Social Work in Education, 22: 46-53.

[4] Bassey M 1995. Creating Education through Research. New York: Kirklington Press.

[5] Enomoto E 1997. Negotiating the ethics of care and justice. Educational Administration Quarterly, 33:351-370.

[6] Fleming N 1995. Attendance. Why don't They Attend? London: Macmillan Press.

[7] Kottasz R 2005. Reasons for non-attendance at lectures and tutorials. University Teaching and Learning, 2: 5-16.

[8] Lotz R, Lee L 1999. Sociability, school experience and delinquency. Youth and Society, 31: 351370.

[9] Williams B 1999. Education, Social Structure and Development: A Comparative Analysis. London: Macmillan Press

*Corresponding author.

E-mail address: bsguptaedu@ gmail.com 